\title{
Effects of Caribbean sponge secondary metabolites on bacterial surface colonization
}

\author{
Sarah R. Kelly ${ }^{1}$, Eliane Garo ${ }^{2}$, Paul R. Jensen ${ }^{2}$, William Fenical ${ }^{2}$, Joseph R. Pawlik ${ }^{1, *}$ \\ ${ }^{1}$ Department of Biology and Marine Biology, Center for Marine Science, University of North Carolina at Wilmington, \\ Wilmington, North Carolina 28403, USA \\ ${ }^{2}$ Center for Marine Biotechnology and Biomedicine, Scripps Institution of Oceanography, University of California, San Diego, \\ La Jolla, California 92093, USA
}

\begin{abstract}
Crude organic tissue extracts from 8 species of Caribbean sponges were assayed for inhibitory effects on surface colonization using 24 environmental marine bacterial isolates, 4 known marine invertebrate pathogens, and 1 common fouling bacterium. Each extract was tested for its effects on bacterial attachment, growth and swarming. The 24 bacterial strains were isolated from sponge surfaces, nearby substrata, or adjacent seawater. Extracts were incorporated into agar for assays of bacterial attachment and swarming. Growth-inhibition assays were conducted with the standard agar disk-diffusion assay. Of the 24 bacterial isolates, 23 were significantly inhibited from attaching to an extract-treated agar surface; 1 isolate from the surface of Agelas conifera exhibited significantly enhanced attachment on agar treated with the extract of that sponge. Sponge extracts had the least effect on growth: of 184 assays, 11 displayed significant antibacterial activity, all of these from 4 sponge species (A. conifera, Ailochroia crassa, Amphimedon compressa, and Aplysina fulva). The same isolate from the surface of $A$. conifera that exhibited enhanced attachment in response to the extract of that sponge exhibited inhibited growth in response to the same extract. Six out of 24 bacterial isolates exhibited swarming, the majority $(67 \%)$ of which were isolated from substratum sources. Extracts from 4 of the 8 sponge species (the same species as listed above) inhibited swarming in all 6 strains, while the remaining extracts enhanced, inhibited, or had no effect on swarming depending on the strain. Bioassay-guided fractionation of the extract of A. crassa yielded 2 compounds responsible for inhibiting attachment and swarming, respectively. Ianthellin was identified as the metabolite that inhibited attachment, whereas another brominated tryosine metabolite inhibited swarming. Chemical defenses of sponges may target microbial attachment, and to a lesser degree influence swarming and growth. Non-toxic metabolites may play the greatest role in affecting bacterial epibiosis on the surfaces of marine sponges.
\end{abstract}

KEY WORDS: Bacterial attachment $\cdot$ Bacterial swarming $\cdot$ Bromotyrosine metabolites $\cdot$ Microbial chemical defense $\cdot$ Quorum sensing · Antibacterial

Resale or republication not permitted without written consent of the publisher

\section{INTRODUCTION}

Marine invertebrates and plants are constantly exposed to bacteria, which typically occur in seawater at concentrations of approximately $10^{6}$ cells ml-1 . Many of these bacteria are motile, chemotatic, opportunistically pathogenic, and readily attach after encountering a suitable surface. However, very little is known about how marine organisms respond to bacteria and how bacteria respond to the host surface environment (Davis et al. 1989, Maximilien et al. 1998, Steinberg 2001).

Bacterial epibiosis can be disadvantageous for the host. For example, pathogenic bacteria in host-associated biofilms can cause significant degradation of host tissue (Correra \& Sanchez 1996) and even mortality (Littler \& Littler 1995). Biofilms may also enhance the colonization of larger fouling organisms (Kirchman et al. 1982, Holmstrom \& Kjelleberg 1994), which can 
create additional problems for the host. In response to epibiosis, many organisms have evolved defenses to combat microbial attachment as well as fouling by larger settling organisms. These defenses include the production of special surface structures, continuous surface renewal, mucus production, or the production of inhibitory compounds (Dyrnda 1986, Davis et al. 1989, Wahl 1989, Wahl \& Banaigs 1991, Pawlik 1992). Alternatively, some organisms can tolerate bacterial epibiosis and even total overgrowth by larger fouling organisms, and may benefit from their associated biofilms (Stoecker 1978, Dyrnda 1986).

Sponges are sessile invertebrates with few obvious physical defenses (Chanas \& Pawlik 1995). They rely on chemical defenses for protection against predators and overgrowth by neighboring organisms (Porter \& Targett 1988, Pawlik 1993, Pawlik et al. 1995, Engel \& Pawlik 2000). Sponges are ideal candidates for antifouling chemical defenses because they produce a wide variety of unusual secondary metabolites and generally exhibit clean surfaces (Blunt et al. 2004 and references therein). Although bacteria are known to comprise up to $60 \%$ of the biomass in some sponge species (Willenz \& Hartman 1989), there are also sponges that contain only sparse numbers of bacteria on the outside and inside of their tissues (Vacelet \& Donadey 1977, Becerro et al. 1994, Hentschel et al. 2003). Given the abundance of fouling organisms present in seawater, it seems likely that any immersed living surface that is free of epibionts must produce some type of antifouling defense (Wahl 1989, Becerro et al. 1994).

Sponge compounds may affect any, or all, of the multiple stages in bacterial surface colonization, which generally consists of directional swimming, attachment, surface motility, and biofilm formation (Wahl 1989, Steinberg 2001). Recent studies indicate that metabolites from benthic marine organisms may interfere with specific stages of this colonization process (Steinberg et al. 1997, Maximilien et al. 1998). Compounds may specifically inhibit bacterial attachment or swarming rather than inhibiting growth or causing cell death (Wahl et al. 1994, Slattery et al. 1995, Maximilien et al. 1998). For example, Maximilien et al. (1998) demonstrated that furanones from the red alga Delisea pulchra inhibited swarming, a coordinated multicellular response that bacteria use to rapidly spread across a surface (Harshey 1994, Belas 1996). Swarming was inhibited at concentrations that had no effect on bacterial cell division and colony growth.

Several studies have demonstrated a correlation between antimicrobial activity in laboratory assays and the absence of microbial fouling in the field (Wahl et al. 1994, Slattery et al. 1995, Maximilien et al. 1998). Organisms that produce compounds that interfere with different stages of the colonization process may have a selective advantage over those that produce broadspectrum toxins or general antibiotics (Maximilien et al. 1998, Newbold et al. 1999). These advantages include providing a more targeted approach to inhibiting bacterial colonization while minimizing the risk of autotoxicity (Maximilien et al. 1998).

In the present study, crude organic tissue extracts from 8 species of sponges were investigated for their effects on 3 different stages of bacterial colonization: attachment, growth and swarming. Sponge extracts were tested using 29 different bacterial strains: 24 environmental strains isolated from the surfaces of the sponges, nearby substrata, or adjacent seawater; 4 opportunistic pathogens of marine invertebrates; and 1 fouling bacterium. The 8 sponge species were chosen from 25 that were previously investigated for the effects of sponge organic extracts on the inhibition of attachment by the marine bacterium Vibrio harveyi (Kelly et al. 2003). Extracts from 6 of the sponges (Agelas conifera, Ailochroia crassa, Amphimedon compressa, Aplysina fulva, Ectyoplasia ferox, and Erylus formosus) significantly inhibited attachment of $V$. harveyi, while the remaining 2 sponges (Mycale laxissima and Lissodendoryx isodictyalis) did not. In addition, bioassay-directed fractionation was used to isolate and identify compounds from the crude extract of $A$. crassa that were responsible for inhibiting specific stages of bacterial colonization.

\section{MATERIALS AND METHODS}

Sample collection and extraction. Tissue samples from 8 species of sponges (Table 1) were collected from coral reefs during 2 research expeditions: one in the Bahamas aboard the RV 'Seward Johnson' in March 2001, and the other at NOAA's Undersea Research Center in Key Largo, Florida, USA, in October 2001. For each sponge species, 3 to 6 replicate tissue samples were collected from geographically distant locations ( $>10 \mathrm{~km}$, to avoid collecting asexual clones). Ailochroia crassa, Ectyoplasia ferox, Erylus formosus, and Mycale laxissima were collected in the Bahamas at either Cat Island $\left(24^{\circ} 08.37^{\prime} \mathrm{N}, 75^{\circ} 22.50^{\prime} \mathrm{W}\right)$, Great Stirup Cay $\left(25^{\circ} 49.66^{\prime} \mathrm{N}, 77^{\circ} 54.346^{\prime} \mathrm{W}\right)$, Little San Salvador $\left(24^{\circ}\right.$ $\left.32.90^{\prime} \mathrm{N}, \quad 75^{\circ} 56.01^{\prime} \mathrm{W}\right)$, Long Island $\left(23^{\circ} 38.49^{\prime} \mathrm{N}\right.$, $\left.75^{\circ} 21.50^{\prime} \mathrm{W}\right)$, San Salvador $\left(24^{\circ} 01.11^{\prime} \mathrm{N}, 74^{\circ} 32.68^{\prime} \mathrm{W}\right)$, South Eleuthra $\left(24^{\circ} 41.49^{\prime} \mathrm{N}, 76^{\circ} 14.34^{\prime} \mathrm{W}\right)$, or Sweetings Cay $\left(26^{\circ} 33.451^{\prime} \mathrm{N}, 77^{\circ} 52.88^{\prime} \mathrm{W}\right)$. One replicate of Amphimedon compressa was collected from Great Stirrup Cay. Agelas conifera, A. compressa, and Aplysina fulva were collected in the Florida Keys at either Conch Reef $\left(24^{\circ} 56.996^{\prime} \mathrm{N}, \quad 080^{\circ} 27.223^{\prime} \mathrm{W}\right)$, Dixie Shoals $\left(25^{\circ} 04.660^{\prime} \mathrm{N}, 080^{\circ} 18.740^{\prime} \mathrm{W}\right)$, North Dry Rocks $\left(25^{\circ}\right.$ 


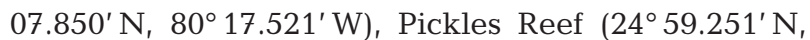
$\left.80^{\circ} 24.64^{\prime} \mathrm{W}\right)$, or White Banks $\left(25^{\circ} 02.585^{\prime} \mathrm{N}\right.$, $80^{\circ}$ $\left.22.170^{\prime} \mathrm{W}\right)$. Lissodendoryx isodictyalis was collected in the Florida Keys at 4 mangrove sites $\left(25^{\circ} 07.923^{\prime}\right.$ $\mathrm{N}$, $080^{\circ} 25.246^{\prime} \mathrm{W}_{i} 25^{\circ} 08.047^{\prime} \mathrm{N}$, $080^{\circ} 25.512^{\prime} \mathrm{W} ; 2^{\circ}$ $08.088^{\prime} \mathrm{N}, \quad 080^{\circ} 25.423^{\prime} \mathrm{W} ; 2^{\circ} 10.395^{\prime} \mathrm{N}, \quad 080^{\circ} 23.170^{\prime}$
W). Samples were collected using SCUBA at depths of 1 to $30 \mathrm{~m}$. Tissue samples were taken from each sponge using a scalpel, and were immediately frozen $\left(-20^{\circ} \mathrm{C}\right)$ prior to extraction.

Sponge tissue samples were thawed and cut into approximately $1 \mathrm{~cm}^{3}$ pieces. Sample volumes were

Table 1. Sponge extracts and bacterial strains used in assays. Environmental strains: SP = sponge surface isolate, SUB = substratum isolate, $\mathrm{SW}=$ seawater isolate. Fouling and pathogenic strains: $\mathrm{F} 1=$ Cobetia marina, $\mathrm{P} 1=$ Aerococcus viridans, $\mathrm{P} 2=$ Leucothrix mucor, P3 = Vibrio harveyi, P4 = Vibrio parahaemolyticus. Closest sequence matches from NCBI BLASTn searches are indicated with percent similarity values created using the RDPII Phylip interface. nd = not determined. Note these identity matches: SW1 = SW2, SP2 = SP4, WUB6 = SUB7, SP3 = SW3

\begin{tabular}{|c|c|c|c|c|c|c|}
\hline $\begin{array}{l}\text { Sponge extract/ } \\
\text { source location }\end{array}$ & $\begin{array}{l}\text { Bacterial strain } \\
\text { (accession no.) }\end{array}$ & $\begin{array}{l}\text { Sequence match } \\
\text { (accession no.) }\end{array}$ & $\%$ similarity & $\overline{\text { attachment assay }}$ & $\begin{array}{l}\text { Strains tested in: } \\
\text { growth assay }\end{array}$ & $\overline{\text { swarming assay }}$ \\
\hline $\begin{array}{l}\text { Ailochroia } \\
\text { crassa/ } \\
\text { Bahamas }\end{array}$ & $\begin{array}{c}\text { SP1 } \\
\text { SUB1 } \\
(\text { AY780441) } \\
\text { SW1 } \\
\text { (AY780442) }\end{array}$ & $\begin{array}{c}\text { nd } \\
\text { Vibrio sp. } \\
\text { (AY034144) } \\
\text { Uncultured } \\
\text { proteobacterium } \\
\text { (AJ310691) }\end{array}$ & $\begin{array}{c}\text { nd } \\
99.4 \\
100\end{array}$ & $\begin{array}{l}\text { SP1, SUB1, } \\
\text { SW1 }\end{array}$ & All strains & $\begin{array}{l}\text { SP1, SUB1, } \\
\text { F1, P2-4 }\end{array}$ \\
\hline $\begin{array}{l}\text { Ectyoplasia } \\
\text { ferox/ } \\
\text { Bahamas }\end{array}$ & $\begin{array}{c}\text { SP2 } \\
\text { (AY780443) } \\
\text { SUB2 } \\
\text { (AY780449) } \\
\text { SW2 } \\
\text { (AY780444) }\end{array}$ & $\begin{array}{c}\text { Alteromonas sp. } \\
\text { (AB015135) } \\
\text { Dietzia maris } \\
\text { (X79291) } \\
\text { Uncultured } \\
\text { proteobacterium } \\
\text { (AJ310691) }\end{array}$ & $\begin{array}{r}100 \\
99.7 \\
100\end{array}$ & $\begin{array}{l}\text { SP2, SUB2, } \\
\text { SW2 }\end{array}$ & All strains & $\begin{array}{c}\text { SP1, SUB1, } \\
\text { F1, P2-4 }\end{array}$ \\
\hline $\begin{array}{l}\text { Erylus } \\
\text { formosus/ } \\
\text { Bahamas }\end{array}$ & $\begin{array}{c}\text { SP3 } \\
\text { (AY780448) } \\
\text { SUB3 } \\
\text { SW3 } \\
\text { (AY780447) }\end{array}$ & $\begin{array}{l}\text { Halomonas marina } \\
\text { (AJ306890) } \\
\text { nd } \\
\text { Halomonas marina } \\
\text { (AJ306890) }\end{array}$ & $\begin{array}{c}99.4 \\
\text { nd } \\
99.4\end{array}$ & $\begin{array}{c}\text { SP3, SUB3, } \\
\text { SW3 }\end{array}$ & All strains & $\begin{array}{l}\text { SP1, SUB1, } \\
\text { F1, P2-4 }\end{array}$ \\
\hline $\begin{array}{l}\text { Mycale } \\
\text { laxissima/ } \\
\text { Bahamas }\end{array}$ & $\begin{array}{c}\text { SP4 } \\
\text { (AY780437) } \\
\text { SUB4 } \\
\text { (AY780445) } \\
\text { SW4 } \\
\text { (AY780440) }\end{array}$ & $\begin{array}{c}\text { Alteromonas sp. } \\
\text { (AB015135) } \\
\text { Vibrio harveyi } \\
\text { (AY332565) } \\
\text { Pseudomonas sp. } \\
\text { (AB030085) }\end{array}$ & $\begin{array}{r}100 \\
95.1 \\
97.6\end{array}$ & $\begin{array}{l}\text { SP4, SUB4, } \\
\text { SW4 }\end{array}$ & All strains & $\begin{array}{l}\text { SP1, SUB1, } \\
\text { F1, P2-4 }\end{array}$ \\
\hline $\begin{array}{l}\text { Agelas } \\
\text { conifera/ } \\
\text { Florida }\end{array}$ & $\begin{array}{c}\text { SP5 } \\
\text { (AY780435) } \\
\text { SUB5 } \\
\text { SW5 }\end{array}$ & $\begin{array}{l}\text { Bacillus sp. } \\
\text { (AJ244686) } \\
\text { nd } \\
\text { nd }\end{array}$ & $\begin{array}{l}98.8 \\
\text { nd } \\
\text { nd }\end{array}$ & $\begin{array}{l}\text { SP5, SUB5 } \\
\text { SW5 }\end{array}$ & $\begin{array}{c}\text { SP5-8, SUB5-8 } \\
\text { SW5-8, F1, } \\
\text { P2-4 }\end{array}$ & $\begin{array}{c}\text { SUB5, SUB6, } \\
\text { SW6, SUB8, } \\
\text { F1, P2-4 }\end{array}$ \\
\hline $\begin{array}{l}\text { Amphimedon } \\
\text { compressa/ } \\
\text { Florida }\end{array}$ & $\begin{array}{c}\text { SP6 } \\
\text { (AY780433) } \\
\text { SUB6 } \\
\text { (AY780438) } \\
\text { SW6 } \\
\text { (AY780446) }\end{array}$ & $\begin{array}{c}\text { Bacillus sp. } \\
\text { (AB055097) } \\
\text { Vibrio harveyi } \\
\text { (AY332565) } \\
\text { Pseudoalteromonas sp. } \\
\text { (AF227238) }\end{array}$ & $\begin{array}{r}100 \\
100 \\
99.7\end{array}$ & $\begin{array}{l}\text { SP6, SUB6 } \\
\text { SW6 }\end{array}$ & $\begin{array}{c}\text { SP5-8, SUB5-8, } \\
\text { SW5-8, F1, } \\
\text { P2-4 }\end{array}$ & $\begin{array}{c}\text { SUB5, SUB6, } \\
\text { SW6, SUB8, } \\
\text { F1, P2-4 }\end{array}$ \\
\hline $\begin{array}{l}\text { Aplysina } \\
\text { fulva/ } \\
\text { Florida }\end{array}$ & $\begin{array}{c}\text { SP7 } \\
\text { SUB7 } \\
(\text { AY780439) } \\
\text { SW7 } \\
\text { (AY780450) }\end{array}$ & $\begin{array}{c}\text { nd } \\
\text { Vibrio harveyi } \\
\text { (AY332565) } \\
\text { Pseudoalteromonas sp. } \\
\text { (AF227238) }\end{array}$ & $\begin{array}{l}\text { nd } \\
100 \\
100\end{array}$ & $\begin{array}{l}\text { SP7, SUB7 } \\
\text { SW7 }\end{array}$ & $\begin{array}{c}\text { SP5-8, SUB5-8 } \\
\text { SW5-8, F1, } \\
\text { P2-4 }\end{array}$ & $\begin{array}{c}\text { SUB5, SUB6, } \\
\text { SW6, SUB8, } \\
\text { F1, P2-4 }\end{array}$ \\
\hline $\begin{array}{l}\text { Lissodendoryx } \\
\text { isodictyalis/ } \\
\text { Florida }\end{array}$ & $\begin{array}{c}\text { SP8 } \\
(\mathrm{AY780434)} \\
\text { SUB8 } \\
(\mathrm{AY780436)} \\
\text { SW8 }\end{array}$ & $\begin{array}{l}\text { Bacillus firmus } \\
\text { (D16268) } \\
\text { Bacillus sp. } \\
\text { (AJ244686) } \\
\text { nd }\end{array}$ & $\begin{array}{c}99.4 \\
98.8 \\
\text { nd }\end{array}$ & $\begin{array}{l}\text { SP8, SUB8 } \\
\text { SW8 }\end{array}$ & $\begin{array}{c}\text { SP5-8, SUB5-8 } \\
\text { SW5-8, F1, } \\
\text { P2-4 }\end{array}$ & $\begin{array}{c}\text { SUB5, SUB6, } \\
\text { SW6, SUB8, } \\
\text { F1, P2-4 }\end{array}$ \\
\hline
\end{tabular}


then quantified by solvent displacement in a graduated cylinder by adding tissue to $200 \mathrm{ml}$ of methanol until a final volume of $400 \mathrm{ml}$ was obtained. Samples were extracted in methanol for $24 \mathrm{~h}$, the resulting solution filtered, and the extract concentrated by rotary evaporation. Samples were re-extracted in 1:1 methanol:dichloromethane for a further $24 \mathrm{~h}$, the solution filtered, and the 2 extracts combined and dried by rotary evaporation. This crude organic extract, representing the amount of material obtained from $200 \mathrm{ml}$ of sponge tissue, was then solubilized, transferred to scintillation vials, and dried under high vacuum. Crude extracts were stored under nitrogen at $-20^{\circ} \mathrm{C}$.

Bacterial isolation and characterization. Bacterial strains (24) were isolated from the 8 previously described sponges or their surrounding environment in the Bahamas and Florida Keys (Table 1). Three bacterial strains were isolated for each of the 8 sponge species: one from the surface of each sponge, one from the substratum near each sponge, and one from a seawater sample collected near each sponge. Sponge surface, substratum, and seawater strains were designated SP1 to 8, SUB1 to 8, and SW1 to 8, respectively. For example, the bacterial strains isolated from the surface of Ailochroia crassa and from its surrounding habitat are designated SP1, SUB1, and SW1 (Table 1). Bacterial strains associated with A. crassa, Ectyoplasia ferox, Erylus formosus, and Mycale laxissima were collected from Cat Island, Little San Salvador, San Salvador and Great Stirrup Cay, respectively. Bacterial strains associated with Agelas conifera, Amphimedon compressa, Aplysina fulva, and Lissodendoryx isodictyalis were collected from Conch Reef, North Dry Rocks, Pickles Reef, and 1 of the 4 mangrove sites $\left(25^{\circ} 07.923^{\prime} \mathrm{N}, 080^{\circ} 25.246^{\prime} \mathrm{W}\right)$, respectively.

Bacteria associated with sponge surfaces (Strains SP1 to 8) were isolated from small pieces of sponge tissue that had been rinsed with sterile seawater. A sterile cotton applicator was gently rubbed over an area of approximately $3 \mathrm{~cm}^{2}$ and the applicator was used to inoculate a B1 medium plate containing peptone $(2.5 \mathrm{~g}$ $\left.\mathrm{l}^{-1}\right)$, yeast extract $\left(1.5 \mathrm{~g} \mathrm{l}^{-1}\right)$, glycerol $\left(1.5 \mathrm{ml} \mathrm{l}^{-1}\right)$, and agar $\left(16 \mathrm{~g} \mathrm{l}^{-1}\right)$ in seawater. The same procedure was used to isolate substratum surface strains (SUB1 to 8) except that the source material was the limestone 'pavement' characteristic of coral reef environments. Seawater strains (SW1 to 8) were isolated from seawater collected in small, sterile plastic bags. A $50 \mu \mathrm{l}$ subsample of freshly collected seawater from each bag was spread with a sterile glass rod onto the surface of a B1 medium plate. Pure cultures were obtained by repeated transfer of single colonies on plates of B1 medium. All strains were grown in liquid B1 and cryopreserved $\left(-80^{\circ} \mathrm{C}\right)$ in a $10 \%$ glycerol solution for future use.
Strains were selected for assays based on 3 criteria: (1) colony morphology, (2) motility, and (3) ability to attach to an agar surface. Motility was determined by examining seawater wet mounts using phase contrast microscopy $(1250 \times)$. Bacterial attachment to an agar surface was determined using an assay from Kelly et al. (2003), which was modified from one originally described by Wahl et al. (1994).

Eighteen of the 24 environmental isolates were characterized by small subunit (SSU)16S rRNA gene sequence analysis. Six isolates did not remain viable and were not sequenced. Genomic DNA was prepared using a Qiagen Dneasy kit (www.quiagen.com) according to the manufacturer's instructions. The SSU rRNA gene was PCR amplified using the primers FC27 (5'-AGAGTTTGATCCTGGCTCAG-3') and RC1492 (5'-TACGGCTACCTTGTTACGACTT-3') or F27 (5'AGAGTTTGATCMTGGCTCAG-3') and R1492 (5'TACGGYTACCTTGTTACGACTT-3') and the products purified using a Qiagen QIAquick PCR cleanup kit following the manufacturer's protocols (Qiagen). PCR products were quantified and submitted to the University of California, San Diego Cancer Center DNA Sequencing Shared Resource for sequencing (3100 Genetic Analyzer, PE-Applied Biosystems) using the primers FC27 or F27. Partial SSU rRNA gene sequences (ca. $0.6 \mathrm{~kb}$ ) were searched using the NCBI BLAST (Blastn) online analysis and related sequences imported into the Ribosomal Database Project (RDPII). The RDPII Phylip interface (Michigan State University, release number 8.1) was used to create a similarity matrix using the Kimura 2-parameter method. The sequence data were deposited in GenBank and assigned the accession numbers AY780433 to AY780450 (Table1).

Attachment bioassay. Crude extracts of the 8 sponges were tested for the inhibition of attachment by bacterial strains that were collected from the same habitat as the sponge (Table 1). The first step in the attachment bioassay was to incorporate each sponge extract into a volumetric equivalent of molten agar $\left(60^{\circ} \mathrm{C}\right)$. To ensure a homogeneous mixture of extract and agar, the extract (10 ml volumetric equivalent) was first solubilized in $0.5 \mathrm{ml}$ acetone. Ten $\mathrm{ml}$ of molten agar (YP medium, $60^{\circ} \mathrm{C}$ ) were added to the resuspended crude extract and the mixture swirled to drive off the solvent. The homogeneous extract-agar mixture was then pipetted into a sterile Petri plate to a depth of $1 \mathrm{~mm}$ and allowed to cool. Control plates were prepared using solvent only. Five $1 \mathrm{~cm}^{2}$ blocks were cut with a sterile scalpel and removed from each extract-agar or control plate. Each block was placed in an individual well in a 6-well microtiter plate and represented a control or treatment sub-sample.

Three ml of autoclaved, filtered seawater and 25 to $200 \mu \mathrm{l}$ of bacterial culture grown for $24 \mathrm{~h}$ in medium YP 
(yeast extract, $1 \mathrm{~g} \mathrm{l}^{-1}$; peptone, $1 \mathrm{~g} \mathrm{l}^{-1}$; agar, $16 \mathrm{~g} \mathrm{l}^{-1}$ in seawater) and adjusted to a standard optical density (600 $\mathrm{nm}$ ) by the addition of sterile seawater were added to each well of the microtiter plate. The volume of inoculum was predetermined in preliminary tests of each bacterial species so as to yield countable numbers of attached bacteria. Blocks were exposed to the bacterial suspension for $2 \mathrm{~h}$, after which $300 \mu \mathrm{l}$ of $37 \%$ formaldehyde was added to fix the bacteria. After $10 \mathrm{~min}, 40 \mu \mathrm{l}$ of DAPI (4',6-diamidino-2-phenyindole) was added to stain bacterial DNA. Blocks were then transferred to a petri dish containing autoclaved, filtered seawater and swirled gently for $10 \mathrm{~s}$ to remove unattached bacteria.

Control and extract-treated blocks were mounted on slides and examined with an Olympus BH-60 epifluorescence microscope under ultraviolet excitation. Bacteria were quantified using epifluorescent direct counting (Kepner \& Pratt 1994), and 10 random fields (each with an area of $0.64 \mathrm{~mm}^{2}$ ) were counted for each $1 \mathrm{~cm}^{2}$ block. Therefore, there were 50 counts (10 field counts for each of 5 blocks) for each replicate sponge extract.

Mean attachment data were determined for 3 to 6 replicate extracts from each sponge species, with each replicate extract from a different sponge sample. Each replicate extract was assayed separately. The mean attachment on the 5 sub-sample blocks of each extract was compared to a control mean. The difference between the control and extract mean was represented as a percentage, so that lower percentage values reflect greater inhibition of bacterial attachment by extracts. The significance of differences between bacterial attachment on treated versus control blocks was evaluated with the Kruskal-Wallis test followed by Dunn's multiple comparison test (Zar 1999).

Growth inhibition bioassay. Extracts of sponges that were collected from the Bahamas were assayed for growth inhibition of all bacterial strains isolated from both the Bahamas and the Florida Keys, while extracts of sponges that were collected in the Florida Keys were assayed only against the strains isolated from the Florida Keys (Table 1). In addition to the environmental strains, 5 additional strains - Aerococcus viridans (P1, ATCC 10400), Cobetia marina (F1, ATCC 25374), Leucothrix mucor (P2, ATCC 25906), Vibrio parahaemolyticus (P4, ATCC 27969), and V. harveyi (P3, identified by fatty acid methyl ester [FAME] analysis, similarity index 0.95; Microbial ID, see www.midi-inc.com; using Sherlock Microbial ID system) - were also assayed against the extracts of all 8 sponges. C. marina is a common surface fouling bacterium (Shea et al. 1995). The latter 3 strains are known to cause disease in marine invertebrates (Sparks 1985). V. harveyi was isolated and identified as part of a related study (Kelly et al. 2003). Strains of $V$. harveyi are also known to be opportunistically pathogenic for some marine fish and invertebrates (Lui et al. 1996, Alcaide et al. 2001).

Inhibition of growth was determined using a standard agar disc-diffusion assay (Jensen et al. 1996, Newbold et al. 1999). Assay plates were incubated at $30^{\circ} \mathrm{C}$ until a homogeneous bacterial lawn developed on the agar surface, usually within $24 \mathrm{~h}$. Areas of bacterial growth inhibition were observed as clear zones surrounding the disc and recorded as the total area minus the area of the disk (6 $\mathrm{mm}$ diameter). Sponge species for which the mean of the replicate extracts produced cleared zones with a radius greater than $3 \mathrm{~mm}$ (area $=35 \mathrm{~mm}^{2}$ ) were considered to possess antibacterial activity. The disk-diffusion assay is used to assess qualitative differences in antibacterial activity and is not without limitations (Jensen et al. 1996, Jenkins et al. 1998, see 'Discussion'). Therefore, statistical analyses were not used to assign significance between treatments (see Newbold et al. 1999).

Swarming strain selection and bioassay. Bacterial swarming is a multicellular behavior in which cells in a colony elongate, hyperflagellate and then rapidly spread over a surface in an organized movement (Henrichsen 1972, Harshey 1994, Belas 1996). From an inoculation point on an agar surface, swarming can be observed macroscopically as a continuous, circular film of thin growth or as a series of regularly spaced, concentric zones of thickened growth (Belas 1996). In addition to macroscopic observation, swarming can be confirmed by observing colony rims under light microscopy at $400 \times$ magnification. The cells present at the edge of a swarming colony display a coordinated multicellular movement, as described by Belas (1996) and Henrichsen (1972), and can be differentiated from another type of surface motility (swimming) by observing cell behavior on different viscosities of agar media (Henrichsen 1972, Harshey 1994).

The presence of swarming was investigated for all 24 bacterial strains using macroscopic and microscopic identification. B1 medium plates with $0.6 \%$ agar and $0.3 \%$ casamino acids were used in the screening (Eberl et al. 1999). Of the 24 strains, 6 (25\%) swarmed, and these-as well as 4 additional swarming strains: Cobetia marina (F1), Leucothrix mucor (P2), Vibrio harveyi (P3) and V. parahaemolyticus (P4)-were chosen for the swarming bioassay.

Bacterial strains were observed for the presence of swarming on B1 medium containing sponge extracts at natural concentrations. The extracts of sponges collected in the Bahamas were assayed against the swarming strains from the Bahamas (SP1 and SUB1) as well as the fouling and pathogenic strains F1 and P2 to P4 (Table 1). The extracts of sponges collected 
in the Florida Keys were assayed against the swarming strains from the Florida Keys (SUB5, SUB6, SW6, and SUB8) as well as the fouling and pathogenic strains F1 and P2 to P4 (Table 1). Sponge extracts $(20 \mathrm{ml}$ volumetric equivalents) were incorporated into $20 \mathrm{ml}$ molten $\left(60^{\circ} \mathrm{C}\right) \mathrm{B} 1$ medium $(0.6 \%$ agar). These plates, including 3 to 4 replicates for each sponge species and controls, were allowed to solidify overnight. Bacterial strains were cultured overnight on $\mathrm{B} 1$ medium at $30^{\circ} \mathrm{C}$ and then stab-inoculated in the center of each plate. The area of the swarming colony was observed for $4 \mathrm{~d}$ and digital photos were used to monitor expansion. Image J (US National Institutes of Health), a software program that digitally measures area, was used to record the area over a $4 \mathrm{~d}$ period. Differences in the mean area of the swarm between extract-treated and control plates for each bacterial strain were compared after 4 d using the Mann-Whitney test (Zar 1999).

Bioassay-guided fractionation. Bioassay-guided fractionation of the crude extract of Ailochroia crassa was conducted using the attachment bioassay with Vibrio harveyi (P3). V. harveyi was chosen based on a separate study with $A$. crassa that showed significant

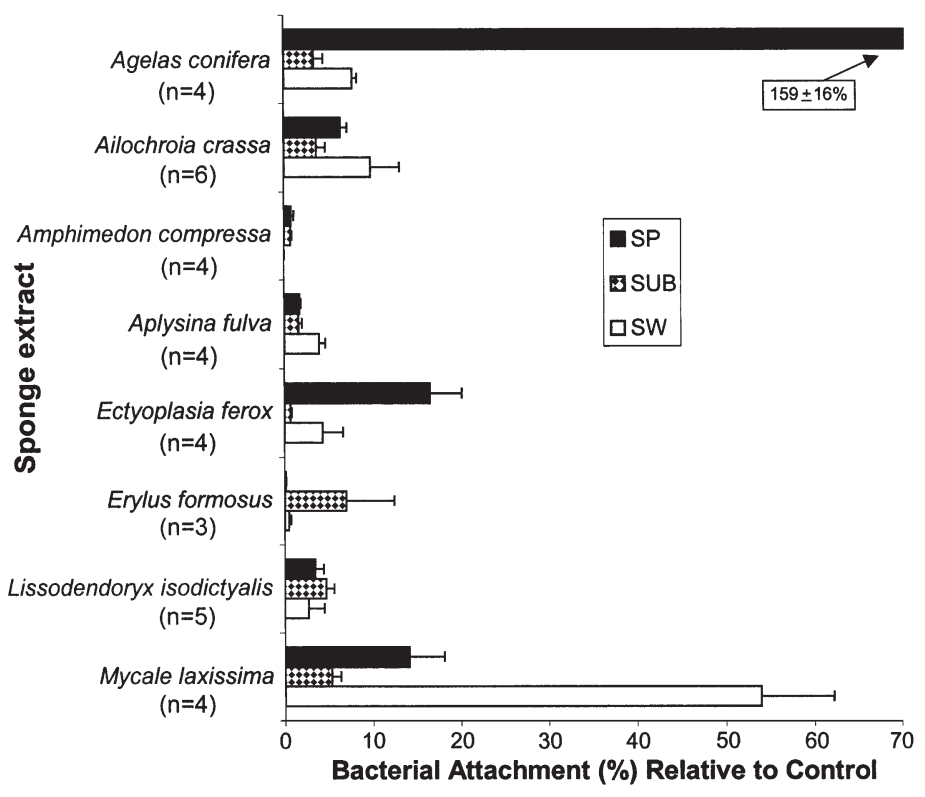

Fig. 1. Percentage attachment of 24 bacteria strains on agar blocks containing volumetrically natural concentrations of Caribbean sponge extracts. Data are expressed as a percentage of attachment on control agar blocks. Mean $+\mathrm{SE}$ is shown for the number of replicate assays performed on extracts prepared from separate samples of sponge tissue ( $\mathrm{N}=3$ to 6$)$. SP: bacterial isolate from the sponge surface: SUB: isolate from the adjacent substratum; SW: isolate from adjacent seawater. See Table 1 for bacterial identities. Extracts significantly inhibited all strains from attaching except for the one for which attachment was significantly enhanced by the extract of Agelas conifera ( $\mathrm{p}<0.0001$, Kruskal-Wallis test) attachment inhibition (Kelly et al. 2003). The crude extract (14.12 $\mathrm{g}$ from $200 \mathrm{ml}$ sponge tissue) was diluted with methanol:water (9:1) and then partitioned against iso-octane. The methanolic portion was adjusted to MeOH: $\mathrm{H}_{2} \mathrm{O}$ (6:4) and partitioned against dichloromethane. All methanol was evaporated from the methanolic layer, and the aqueous solution was partitioned against n-butanol. This resulted in 4 partitions that were tested for activity in the assay. The butanol partition (22 $\mathrm{mg} \mathrm{ml}^{-1}$ ) was determined to be the most active and further separated by reversedphase flash chromatography, eluting with a solvent gradient system of increasing methanol concentration $\left(100 \% \mathrm{H}_{2} \mathrm{O}\right.$ to $\left.100 \% \mathrm{MeOH}\right)$ and ending with the last 2 fractions eluting with dichloromethane/methanol (50:50) and $100 \%$ dichloromethane. This separation resulted in 9 fractions, and the fraction eluting with $60 \% \mathrm{MeOH}$ was the most active in the assay. This fraction (3.6 $\mathrm{mg} \mathrm{ml}^{-1}$ ) was further separated by gel chromatography (Sephadex LH-20, methanol) to yield 30 fractions, 5 of which were active in the attachment assay. These 5 fractions were recombined after analysis by liquid chromatography-mass spectrometry (LC-MS) revealed that they were chemically homogeneous. LC-MS was performed on a Hewlett Packard 1100 series LC system with an electrospray 1100 MSD. The column used for the analyses was a Zorbax ${ }^{\circledR}$ C-8 column with a $3.5 \mu \mathrm{m}$ particle size. Nuclear magnetic resonance (NMR) spectra were recorded at 300 and $400 \mathrm{MHz}$ on Varian Unity INOVA spectrometers. ${ }^{1} \mathrm{H}$ NMR and ${ }^{13} \mathrm{C}$ NMR spectra were referenced to solvent signals at 3.31 and $49.0 \mathrm{ppm}$ for deuteriomethanol. Bioassay-guided fractionation was also performed using $V$. harveyi (P3) in the swarming assay. The same fractions were tested in the swarming assay as in the attachment assay.

\section{RESULTS}

\section{Inhibition of attachment by sponge extracts}

Of the 24 bacterial strains, 23 were significantly inhibited from attaching to the surface of agar containing volumetrically equivalent concentrations of crude organic sponge extracts (Fig. 1, p < 0.0001, KruskalWallis test, Zar 1999). The only bacterial strain that was not inhibited from attachment was a sponge surface strain from Agelas conifera (SP5), which had significantly enhanced attachment in response to the extract of A. conifera ( $\mathrm{p}<0.0001)$.

Differences in the effects of extracts on the attachment of bacteria isolated from different sources (i.e. sponge surface, substratum surface and seawater) were also compared. For the extracts of 4 sponges 
(Ailochroia crassa, Erylus formosus, Aplysina fulva and Lissodendoryx isodictyalis), there were no sourcedependent differences in the sensitivity of the strains. However, substratum isolates were significantly less likely to attach than sponge isolates in assays of extracts of Agelas conifera and Ectyoplasia ferox (Fig. 1, p < 0.01, Kruskal-Wallis test, Zar 1999). Seawater isolates were significantly less likely to attach than substratum isolates in assays of the extract of Amphimedon compressa ( $\mathrm{p}<0.05)$. The opposite was observed when isolates where exposed to the extract of Mycale laxissima ( $\mathrm{p}<0.05)$. Strains that were determined to be closely related based on phylogenetic analyses (i.e. SW1 and SW2, SP2 and SP4, SUB6 and SUB7, SP3 and SW3) were affected similarly by the extracts against which they were assayed.

\section{Inhibition of growth by sponge extracts}

Overall, the crude extracts of the 8 sponge species did not inhibit growth to the same degree to which attachment or swarming was inhibited. Of the 184 assays performed, 11 resulted in mean zones of inhibition $>35 \mathrm{~mm}^{2}$ (Fig. 2). Extracts of 4 sponge species inhibited growth (Agelas conifera, Ailochroia crassa, Amphimedon compressa and Aplysina fulva; Fig. 2). Extracts of Ectyoplasia ferox, Erylus formosus, Lissodendoryx isodictyalis and Mycale laxissima did not inhibit the growth of any bacterial strain.

Growth inhibition activity differed among extracts and bacterial test strains. The sponge isolates were most affected by the extracts, with 6 of the extract/SP interactions resulting in growth inhibition (Fig. 2). Only 1 of the extract/substratum bacteria interactions resulted in growth inhibition (Aplysina fulva/SUB6). Overall, SP5, SP8, and SW8 were the most sensitive in this assay, and the extracts of A. fulva and Ailochroia crassa produced the largest zones of inhibition in SP8 and SW8, respectively. The extract of Agelas conifera inhibited the growth of the strain isolated from its surface, but did not inhibit the seawater or substratum strains that were collected nearby. Among the pathogenic and fouling bacteria, only 1 sponge extract/ bacteria interaction resulted in growth inhibition (A. fulva/Vibrio parahaemolyticus; P4, Fig. 2).

\section{Effects of sponge extracts on swarming}

Of the 24 bacterial strains investigated, 6 exhibited swarming motility (SP1, SUB1, 5,6,8 and SW6; Fig. 3). SUB7 did not swarm despite sequence data that indicate it is phylogenetically identical to SUB6 which did swarm (see Table 1). Four of the swarming strains came from substratum sources. In addition to the 6 swarming environmental strains, sponge extracts were also tested against 3 pathogenic strains (P2 to P4) and 1 fouling strain (F1) that also swarm.
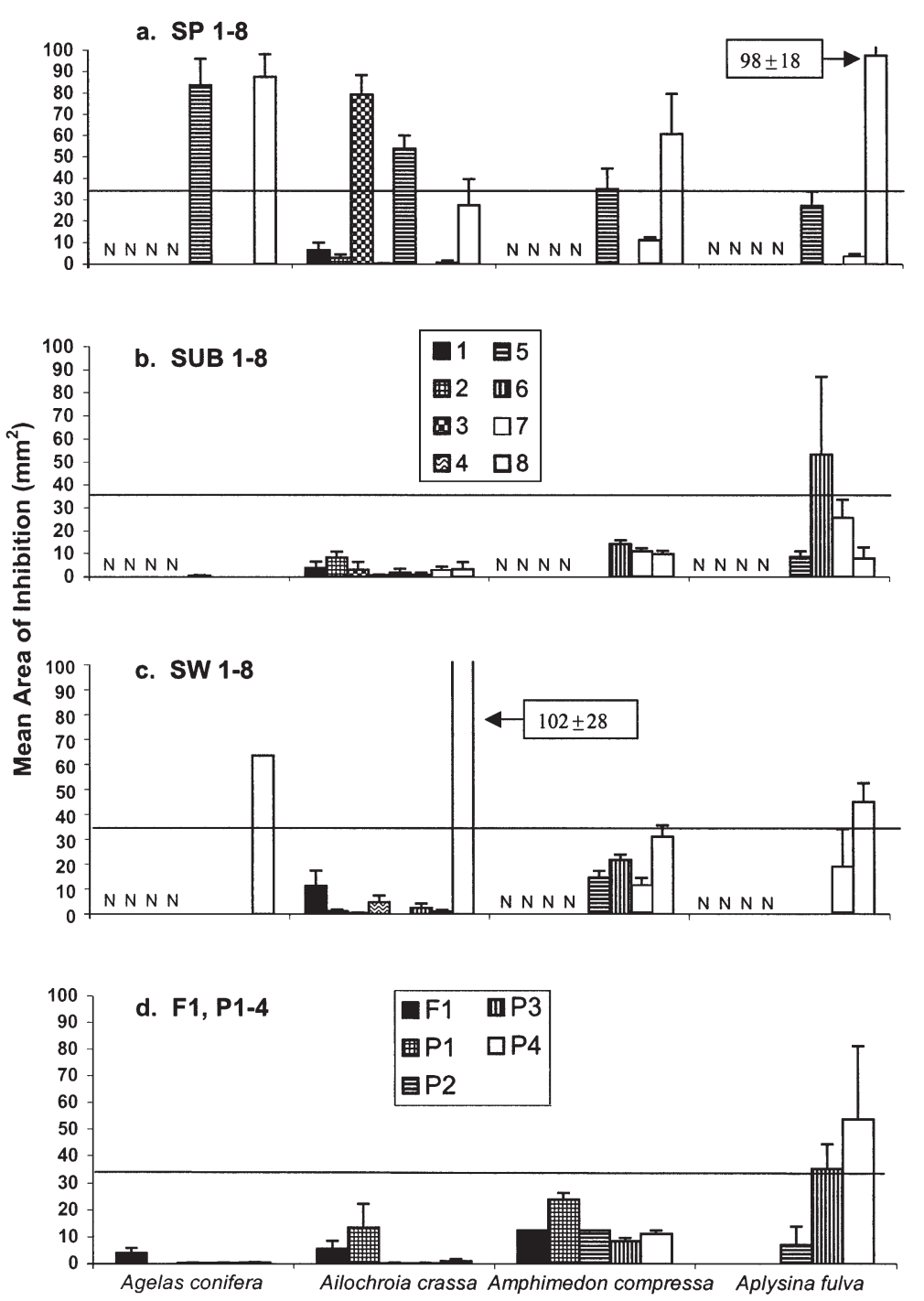

Fig. 2. Area of inhibition of bacterial growth by Caribbean sponge extracts for bacteria isolated from (a) sponge surfaces, (b) adjacent substrata, (c) adjacent seawater, and for (d) pathogenic and fouling strains. Extracts producing a zone of inhibition with an area $>35 \mathrm{~mm}^{2}$ were considered to be active, indicated by the horizontal line in each panel. Data are mean + SE $(\mathrm{N}=4)$. No inhibition was observed in assays of any strains against extracts of Ectyoplasia ferox, Erylus formosus, Mycale laxissima and Lissodendoryx isodictyalis. See Table 1 for bacterial identities and assay combinations. N: not assayed 
$\longrightarrow$ Control
$\longrightarrow$ Ectyoplasia ferox $\rightarrow$ Mycale laxissima
$\longrightarrow$ Lissodendoryx isodictyalis
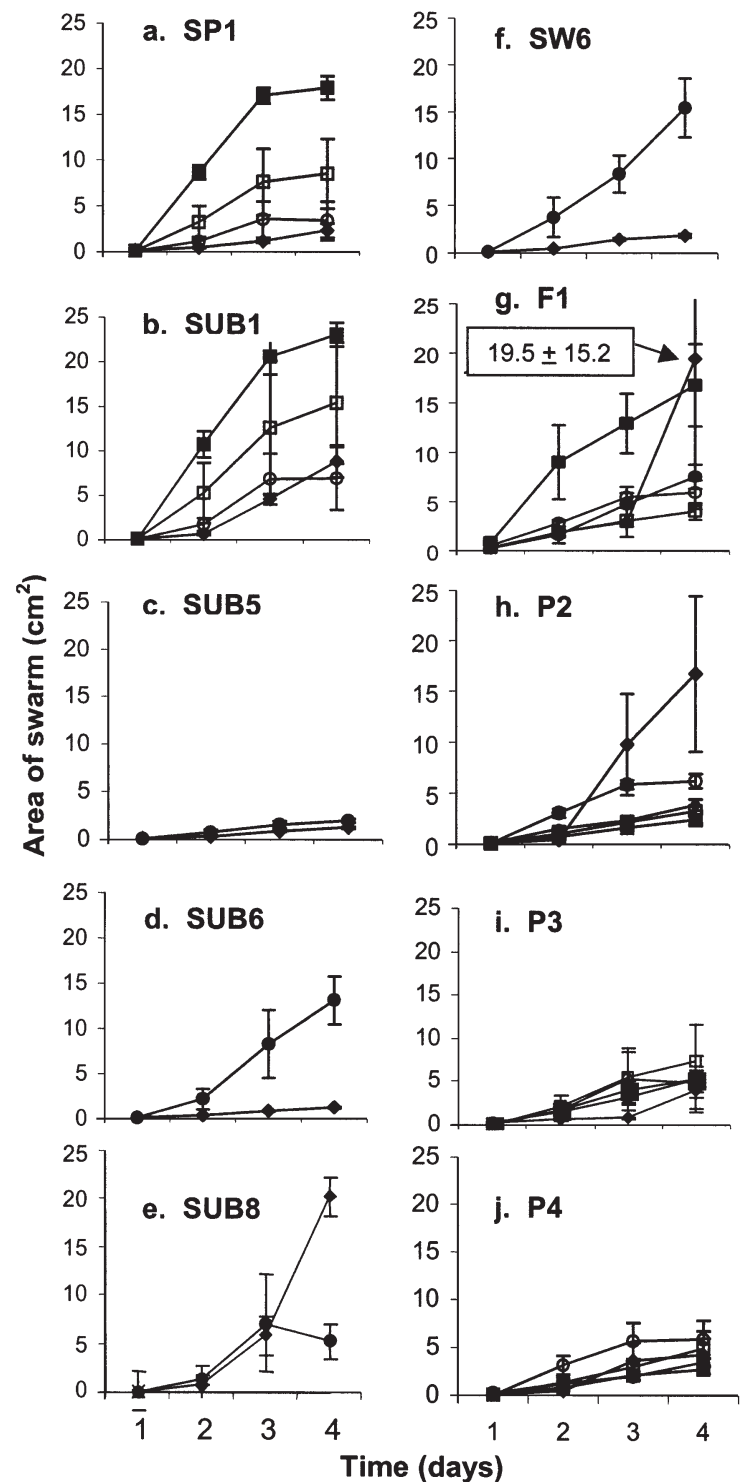

Fig. 3. Swarming of bacteria in response to sponge extracts. Responses of strains (a) SP1 and (b) SUB1 to extracts of Ectyoplasia ferox, Erylus formosus and Mycale laxissima; (c) SUB5, (d) SUB6, (e) SUB8, and (f) SW6 to extracts of Lissodendoryx isodictyali; and (g) F1, (h) P2, (i) P3, and (j) P4 to all 4 sponge extracts. Data are mean $\pm \mathrm{SE}$ for $\mathrm{N}=4$ plates for each strain and each extract. Swarming was not observed for any assays of extracts of Ailochroia crassa, Agelas conifera, Amphimedon compressa and Aplysina fulva. See Table 1 for bacterial identities

Extracts of 4 of the 8 sponge species - 1 from the Bahamas (Ailochroia crassa) and 3 from the Florida Keys (Agelas conifera, Amphimedon compressa and Aplysina fulva) - completely inhibited swarming in all of the strains against which they were tested. These are the same 4 sponge species that generated antibiotic activities in the growth inhibition assays (Fig. 2); however, bacterial growth was always visible at the inoculation site in these swarming assays. Because the mean swarm area for these assays was 0 , the data were not included in Fig. 3.

Among the remaining sponge extracts that showed varying effects on swarming relative to controls, the extract of Ectyoplasia ferox significantly enhanced swarming of SP1 and SUB1 relative to the control by Day 4, but significantly inhibited the swarming of P2 ( $\mathrm{p}<$ 0.01; Mann-Whitney test, Zar 1999). Extracts of Lissodendoryx isodictyalis significantly enhanced the swarming of SUB6 and SW6, but inhibited swarming of SUB8 by Day 4 ( $p<0.01)$. The effects of the remaining extracts on the remaining strains were not significantly different from controls.

\section{Bioassay guided fractionation of the extract of Ailochroia crassa}

Solvent partitioning of a crude extract from Ailochroia crassa concentrated the attachment-inhibitory activity in the n-butanol partition. Flash-column chromatography using reversed-phase C-18 silica gel was performed on the n-butanol-soluble materials, resulting in an active fraction. The fraction was then further separated by gel filtration on Sephadex LH-20. Five active fractions resulted from this separation; these were assayed at natural volumetric concentrations, yielding attachment values ranging from 14 to $61 \%$ (normalized to $100 \%$ of control data). The 5 fractions were recombined after analysis by LC-MS revealed that the fractions had similar profiles. The resulting fraction analyzed by LC-MS showed the presence of the pseudomolecular ion peak cluster $[\mathrm{M}+\mathrm{H}]^{+}$at $\mathrm{m} / \mathrm{z}$ 474,476 , and 478 with peak intensities of $1: 2: 1$, respectively, characteristic of 2 bromine atoms in the molecule. The ${ }^{1} \mathrm{H}$ NMR and ${ }^{13} \mathrm{C}$ NMR spectra showed the presence of 15 carbons and 12 protons that were all in accordance with the chemical shifts recorded for ianthellin (Fig. 4) (Litaudon \& Guyot 1986). The molecular weight of ianthellin is $472.9 \mathrm{amu}$.

The fractions resulting from the procedure described above were also tested for inhibition of swarming by Vibrio harveyi (P3). The most active fraction was again the n-butanol fraction, and this fraction was further fractionated as described above. The fraction that was the most active in the attachment assay was also the most active in the swarming assay. This fraction was separated on an LH-20 sephadex column, resulting in 30 fractions. Fractions 12 to 26 were then tested in the swarming assay at natural volumetric concentrations. Fractions 17 to 21 all contained ianthellin only and 
a

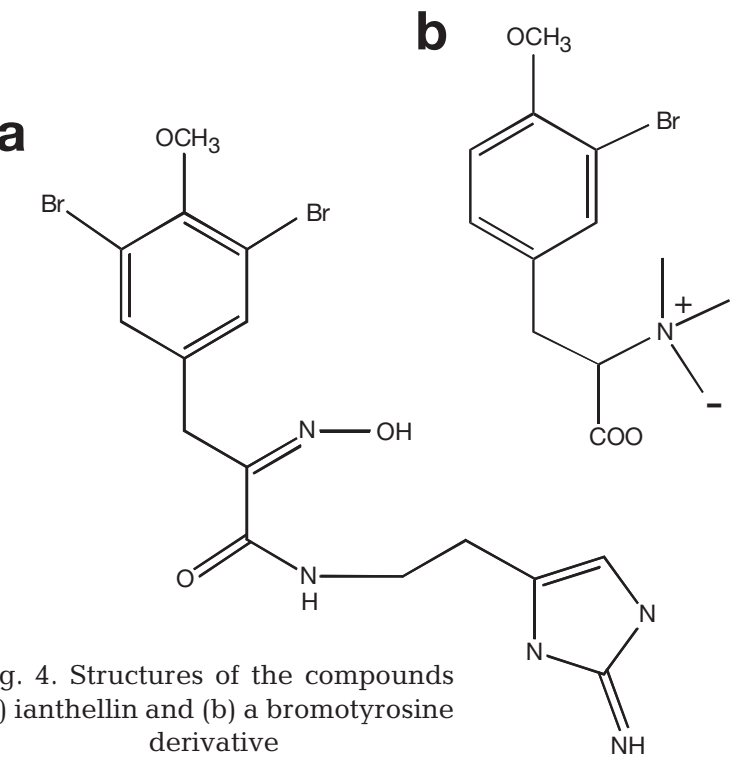

were combined and tested as one. This composite fraction had no effect on swarming relative to the control. The fractions (12 to 14 ) that significantly inhibited swarming did not contain ianthellin $(\mathrm{N}=3$; treatment swarm area: $0.64 \pm 0.13 \mathrm{~cm}^{2}$; control swarm area: $3.41 \pm 0.54 \mathrm{~cm}^{2} ; \mathrm{p}<0.02$, Mann-Whitney test). LC-MS analysis performed on Fractions 12 to 14 showed the presence of a compound that was most pure in Fraction 13. This compound provided a pseudomolecular ion $[\mathrm{M}+\mathrm{H}]^{+}$at $\mathrm{m} / \mathrm{z} 316$ and 318 , as well as the adduct $[\mathrm{M}+\mathrm{Na}]^{+}$at $\mathrm{m} / \mathrm{z} 338$ and 340 . These 2 clusters had equal peak intensities of approximately 1:1. The molecular formula could be deduced from the LC-MS and the NMR data. On the basis of the ${ }^{1} \mathrm{H}$ NMR and ${ }^{13} \mathrm{C}$ NMR chemical shifts recorded in deuteriomethanol, and the MS data, this compound was identified as a known bromotyrosine derivative (Fig. 4) previously isolated from Ailochroia crassa (=Pseudoceratina crassa; Albrizio et al. 1994, Ciminiello et al. 1995).

\section{DISCUSSION}

The ecological roles of sponge secondary metabolites have increasingly been investigated over the past 2 decades, but the focus has primarily been on the anti-predatory roles of these compounds (Paul 1992, Pawlik 1993). Sponge extracts and purified compounds have frequently been found to exhibit antibacterial activities (McCaffrey \& Endean 1985, Thompson 1985), with putative ecological roles varying from killing favorable bacteria for nutrition (Berquist \& Bedford 1978) to inhibiting pathogenic or fouling bacteria (Reiswig 1973, Paul 1992). However, without using relevant assays or environmental strains of bacteria to address ecological questions it has been difficult to definitively assign roles to these metabolites. As a result, little is known about how sponges or other marine eukaryotes mediate interactions between their surfaces and bacteria encountered in their environment (Wahl et al. 1994, Maximilien et al. 1998).

Ecologically relevant evidence that secondary metabolites mediate interactions between marine eukaryotes and bacteria is limited to a few studies (Becerro et al. 1994, Wahl et al. 1994, Slattery et al. 1995, Maximilien et al. 1998, Newbold et al. 1999, Puyana 2001, Kelly et al. 2003). For the most part, these studies correlated the activity of crude extracts or purified secondary metabolites to host epibacterial abundances or showed that crude extracts or secondary metabolites kill bacteria, or inhibit attachment or motility (Becerro et al. 1994, Wahl et al. 1994, Slattery et al. 1995, Maximilien et al. 1998, Newbold et al. 1999). The results of these studies also indicated that interactions between eukaryotes and bacteria could occur without bacterial cell death (Wahl et al. 1994, Slattery et al. 1995, Maximilien et al. 1998). This discovery could be crucial to understanding how these metabolites function in the marine environment.

In the present study, extracts from each of the 8 species of sponges inhibited at least 1 of the characteristics of bacterial colonization: attachment, growth, or swarming. Bacterial attachment was clearly the most inhibited characteristic (Fig. 1). The attachment assay described in this study tests for the effects of sponge extracts or purified metabolites on the whole process of attachment. However, the specific mechanism by which sponge compounds inhibit attachment remains unclear. For example, sponge compounds could inhibit attachment by (1) inducing a negative chemotatic response so that bacteria never encounter the surface, (2) preventing the production of adhesion factors so that bacteria cannot remain on the surface, or (3) inhibiting cell growth or division.

The complex process of bacterial attachment provides multiple possible targets for inhibition by sponge secondary metabolites. Bacterial attachment is strongly affected by the physiological state of the bacterial cell (Fletcher 1996), the production of specific adhesion molecules (Mittleman 1996), and the presence of specific receptor proteins on the surface of the bacterial cell (Doig et al. 1989). Many of the above examples are thought to be under the control of specific regulatory mechanisms. In addition, several genes are thought to be activated when the cell contacts a surface (Dalton et al. 1996). Sponge compounds could possibly act on any or all of these characteristics. By inhibiting these specific pathways, metabolites may be able to act differentially against harmful or beneficial 
bacteria. Interestingly, the extract of Agelas conifera enhanced attachment by Bacillus sp. (SP5) isolated from the surface of that sponge (Fig. 1), suggesting that some bacteria may specifically associate with certain sponges. Oddly, this extract also inhibited the growth of the same strain (Fig. 2), perhaps indicating the presence of metabolites involved in maintaining a stable microbial consortium in the sponge tissue.

Unlike the attachment assay, the swarming assay yielded diverse results, including enhancement of swarming on extract-treated plates relative to control plates (Fig. 3). However, for 30 of the extract/strain assays (specifically, all those using extracts of Ailochroia crassa, Agelas conifera, Amphimedon compressa and Aplysina fulva), swarming was completely inhibited. Extracts of these sponge species were the only ones to show antibiotic effects in the growth-inhibition assay (Fig. 2), but in the swarming assays, growth was clearly evident for all of the test strains at the inoculation point after $4 \mathrm{~d}$. Microscopic examination revealed that these extracts also inhibited motility in all strains, and this may be the mechanism by which swarming was inhibited. Regardless of mechanism, the inhibition of swarming may be an effective antimicrobial chemical defense in sponges. Additional assays of swarming strains in response to lower concentrations of crude extracts, or to isolated compounds from these extracts, would likely help distinguish between possible mechanisms of action. For the remaining assays shown in Fig. 3, swarming was observed, and differential effects of sponge extracts could be discerned, including both enhancement and inhibition of swarming relative to controls.

In addition to inhibiting attachment, the extract of Lissodendoryx isodictyalis was effective at inhibiting bacterial swarming of SUB8 and Leucothrix mucor (P2). The latter was also inhibited from swarming by extracts of Ectyoplasia ferox, Erylus formosus and Mycale laxissima, while the bromotyrosine metabolite purified from Ailochroia crassa extract inhibited the swarming of Vibrio harveyi (P3). Interestingly, extracts of E. ferox, E. formosus and L. isodictyalis enhanced swarming of other bacterial strains (Fig. 3). Swarming is the organized movement of bacterial cells over a surface and is beginning to be recognized as an important mechanism in surface colonization (Belas 1996). For example, the ability of Vibrio parahaemolyticus to differentiate into swarming cells plays an important role in bacterial virulence, surface adsorption, and colonization (Belas \& Colwell 1982, Givskov et al. 1996). Swarming allows bacteria to forage for nutrients on solid surfaces and may provide an adaptive advantage under the low nutrient conditions common in marine environments (Belas 1996). Swarming has been described for many bacterial genera, including Serra- tia, Proteus, Vibrio, Bacillus, Escherichia, Clostridium, Chromobacterium, Azospirillum, Aeromonas, Yersinia, Burkholderia, Pseudomonas, Sinorhizobium and Salmonella (Givskov et al. 1996, Daniels et al. 2004 and references therein), and is controlled by complex signal transduction and genetic regulatory pathways that are referred to as quorum sensing (Harshey 1994, Belas 1996, Maximilien et al. 1998, Daniels et al. 2004). Perhaps the bromotyrosine metabolite from the extract of $A$. crassa interacts specifically to inactivate the quorum sensing system of $V$. harveyi, and may have the same effect on other bacterial species that depend on a quorum sensing system to induce virulence. Interestingly, all 8 sponge extracts of the present study inhibited motility or swarming of L. mucor, a pathogenic and fouling bacterium of marine invertebrates and algae (Sparks 1985). What remains puzzling is the enhancement of swarming observed in several assay combinations, although this may reflect the response of bacteria to the presence of high concentrations of primary metabolites (lipids, sterols, etc.) that are present in crude organic sponge extracts.

Results for the inhibition of bacterial growth in this study were obtained using the standard agar diskdiffusion assay. Although this assay has been used extensively to assess antibacterial activity in previous studies, its limitations should not be ignored (see Jensen et al. 1996, Jenkins et al. 1998 for detailed discussions). For example, compound size, polarity, and charge are all factors that contribute to the diffusion rate of a compound through agar. The effects of compounds that diffuse slowly or not at all, but would otherwise be inhibitory, would not be properly assessed. Despite this, it was clear in many cases that pigmented sponge extracts had diffused through the agar and still had no effect on bacterial growth. In addition, this disk-diffusion assay cannot discriminate between bactericidal or bacteriostatic activities.

Overall, bacterial growth was the least inhibited of all the bacterial colonization traits tested. Similar results have been reported for organic extracts or purified compounds from ascidians and red algae (Wahl et al. 1994, Maximilien et al. 1998). Maximilien et al. (1998) investigated growth inhibition using a different assay, yet also found growth to be less inhibited than other characteristics of bacterial colonization. These results emphasize the importance of investigating the effects of secondary metabolites on multiple stages of bacterial colonization.

Bioassay-guided fractionation of the crude organic extract of Ailochroia crassa led to the isolation of ianthellin (Fig. 4) as the metabolite responsible for the inhibition of bacterial attachment. Although this metabolite had been identified previously (Litaudon \& Guyot 1986), its ecological function remained unex- 
plored. A. crassa is a member of the order Verongida; all species of this order lack spicules, contain brominated tyrosine derivatives, and are devoid of terpene constituents. The secondary metabolites of $A$. crassa have been extensively studied, and in some instances ianthellin is known to be the major secondary metabolite in the organic extract of the sponge (Litaudon \& Guyot 1986, Ciminiello et al. 1995). Considering its high tissue concentrations, ianthellin may play an important role in controlling bacterial populations associated with this sponge.

Important steps in understanding the antibacterial role of sponge secondary metabolites include localizing the metabolites and determining whether compounds are exuded or adhere to the sponge surface. In addition to the structural identification of ianthellin, preliminary data were collected in our laboratory suggesting the presence of this compound on the surface of Ailochroia crassa by localizing bromine in fixed and stabilized sponge tissue samples using energy dispersive $\mathrm{x}$-ray microanalysis (K. Whalen \& J. Pawlik unpubl. data). These preliminary data suggest that ianthellin acts at the surface of the sponge to mediate bacterial colonization. There are obvious limitations to this hypothesis, however. The bromine observed on the surface of A. crassa may be associated with compounds other than ianthellin, and compound concentrations may not be sufficiently high to affect bacteria under natural conditions. In contrast, there is some precedent for this hypothesis: Thompson et al. (1983) described the x-ray localization of brominated secondary metabolites in spherulous cells in the sponge Aplysina fistularis (order Verongida, the same as $A$. crassa). Thompson (1985) further attempted to quantify the exudation rates of these compounds from the sponge, and described negative effects of the compounds on adult and larval fouling organisms using laboratory assays.

Although assays conducted in the present study were performed using bacteria from the same habitat as the sponge, it cannot be ascertained whether these bacteria would respond similarly in the field. A combined approach of laboratory and field assays would be useful in understanding how natural assemblages of bacteria are affected by sponge secondary metabolites. This approach was used in a related study by Kubanek et al. (2002) in which the concentration and location of the metabolite formoside was investigated in the sponge Erylus formosus. Formoside was found to be present on the surface of the sponge at concentrations that inhibited bacterial attachment using the same assay described in the present study, and also inhibited macrofouling in a field assay (Kubanek et al. 2002). These results suggest that $E$. formosus reduces epibiotic micro- and macrofouling through the pro- duction of formoside, and corroborate the conclusions of the present study by suggesting that sponge secondary metabolites have specific effects on bacterial colonization.

There is much to be learned from studies investigating the effects of sponge metabolites on the intricacies of bacterial control, colonization and symbiosis. In the present study, bacterial attachment was clearly the most inhibited characteristic of the colonization process, and bacterial growth was the least. Swarming was inhibited in some cases, but other extracts enhanced swarming (e.g. Ectyoplasia ferox). In addition, purified compounds from Ailochroia crassa, ianthellin and a bromotyrosine metabolite, inhibited bacterial attachment and swarming, respectively. Overall, these results suggest that sponge metabolites may specifically and differentially alter bacterial responses in the environment, and that inhibition of attachment may play a crucial role in the prevention of sponge surface fouling by bacteria.

Acknowledgements. This research was made possible by grants from NOAA's Undersea Research Center at the University of North Carolina at Wilmington (NA 96RU-0260) and from the National Science Foundation, Biological Oceanography Program (OCE-0095724, including UNOLS ship support on the RV 'Seward Johnson'). Research in Key Largo, Florida, was conducted under National Marine Sanctuary Permit FKNMS-2001-021. We thank Tim Henkel, Sebastian Engel, Will O'Neal, Chris Kauffman, Sara Kelly, and Monica Puyana for assistance in diving, specimen collection and scientific discussions. James Blum provided valuable statistical advice. We are grateful to the Government of the Bahamas for permission to perform research in their territorial waters.

\section{LITERATURE CITED}

Albrizio S, Ciminiello P, Fattorusso E, Magno S (1994) Chemistry of the Verongida sponges. I. Constituents of the Caribbean sponge Pseudoceratina crassa. Tetraherdron 50(3):783-788

Alcaide E, Gil-Sanz C, Sanjuan E, Esteve D, Amaro C, Silveira L (2001) Vibrio harveyi causes disease in seahorse, Hippocampus sp. J Fish Dis 24:311-314

Becerro MA, Lopez NI, Turon X, Uriz MJ (1994) Antimicrobial activity and surface bacterial film in marine sponges. J Exp Mar Biol Ecol 179:195-205

Belas R (1996) Sensing, response, and adaptation to surfaces: swarmer cell differentiation and behavior. In: Fletcher M (ed) Bacterial adhesion: molecular and ecological diversity. John Wiley \& Sons, New York, p 1-24

Belas R, Colwell RR (1982) Adsorption kinetics of laterally and polarly flagellated Vibrio. J Bacteriol 151:1568-1580

Berquist RP, Bedford JJ (1978) The incidence of antibacterial activity in marine Demospongiae: systematic and geographic considerations. Mar Biol 46:215-221

Blunt JW, Copp BR, Mnro MH, Northcote PT, Prinsep MR (2004) Marine natural products. Nat Prod Rep 21:1-49

Chanas B, Pawlik JR (1995) Defenses of Caribbean sponges against predatory reef fish: II. Spicules, tissue toughness, and nutritional quality. Mar Ecol Prog Ser 127:195-211 
Ciminiello P, Fattorusso E, Magno S (1995) Chemistry of Verongida sponges. IV. Comparison of the secondary metabolite composition of several specimens of Pseudoceratina crassa. J Nat Prod 58(5):689-696

Correra JA, Sanchez PA (1996) Ecological aspects of algal infectious diseases. Hydrobiologia 326/327:89-96

Dalton H, Goodman AE, Marshall KC (1996) Diversity in surface colonization behavior in marine bacteria. $\mathrm{J}$ Ind Microbiol 17:228-234

Daniels R, Vanderleyden J, Michiels J (2004) Quorum sensing and swarming migration in bacteria. 28:261-289

Davis AR, Targett NM, McConnell OJ, Young CM (1989) Epibiosis of marine algae and benthic invertebrates: natural products chemistry and other mechanisms inhibiting attachment and overgrowth. In: Scheuer PJ (ed) Bioorganic marine chemistry. Springer-Verlag, Berlin, p 85-114

Doig P, Tapping R, Mankinen-Irvin P, Irvin RT (1989) Effect of microcolony formation on the adherence of Pseudomonas aeruginosa to human buccal epithelial cells. Microb Ecol Health Dis 2:203-209

Dyrnda PEJ (1986) Defensive strategies of modular organisms. Phil Trans R Soc Lond Ser B 313:227-243

Eberl L, Molin S, Givskov M (1999) Surface motility of Serratia liquefaciens MG1. J Bacteriol 181(6):1703-1712

Engel S, Pawlik JR (2000) Allelopathic activities of sponge extracts. Mar Ecol Prog Ser 207:273-281

Fletcher M (1996) Bacterial attachment in aquatic environments: a diversity of surfaces and adhesion strategies. In: Fletcher M (ed) Bacterial adhesion: molecular and ecological diversity. John Wiley \& Sons, New York, p 1-24

Givskov M, de Nys R, Manefield M, Gram L and 5 others (1996) Eukaryotic interference with homoserine lactonemediated prokaryotic signaling. J Bacteriol 178(22): 6618-6622

Harshey RM (1994) Bees aren't the only ones swarming: swarming in Gram-negative bacteria. Mol Microbiol 13: 389-394

Henrichsen J (1972) Bacterial surface translocation: a survey and classification. Bacteriol Rev 36:478-503

Hentschel, U, Fieseler L, Wehrl M, Gernert C, Steinert M, Hacker J, Horn M (2003) Microbial diversity of marine sponges. In: Mueller WEG (ed) Marine molecular biotechnology. Springer-Verlag, Berlin, p 59-88

Holmstrom C, Kjelleberg S (1994) The effect of external biological factors on attachment of marine invertebrate larvae and new antifouling technology. Biofouling 8:147-160

Jenkins KM, Jensen PR, Fenical W (1998) Bioassay with marine organisms: Part II. Marine microbial chemical ecology. In: Haynes K, Millar JC (eds) Methods in chemical ecology. Chapman \& Hall, New York, p 1-32

Jensen PR, Harvell CD, Wirtz K, Fenical W (1996) Antimicrobial activity of extracts of Caribbean gorgonian corals. Mar Biol 125:411-419

Kelly SR, Jensen PR, Henkel TP, Pawlik JR (2003) Effects of Caribbean sponge extracts on bacterial attachment. Aquat Microb Ecol 31:175-182

Kepner RL,Pratt JR (1994) Use of fluorochromes for direct enumeration of total bacteria in environmental samples: past and present. Microbiol Rev 58:603-615

Kirchman D, Graham S, Reisch D, Mitchell R (1982) Bacteria induce attachment and metamorphosis of Janua (Dexiospira) brasiliensis Grube (Polychaeta: Spirorbidae). J Exp Mar Biol Ecol 56:153-163

Kubanek J, Whalen KE, Engel S, Kelly S, Henkel T, Pawlik JR (2002) Evidence for multiple defensive roles of triterpene glycosides in sponges. Oecologia 131:125-136
Litaudon M, Guyot M (1986) Ianthelline, un nouveau derive de lfl dibromo-3,5 tyrosine, isole de l'esponge Ianthella ardis (Bahamas). Tetrahedron Lett 27:4455-4456

Littler MM, Littler DS (1995) Impact of CLOD pathogen on Pacific coral reefs. Science 267:1356-1360

Lui PC, Lee KK, Chen SN (1996) Pathogenicity of different isolates of Vibrio harveyi in tiger prawn, Penaeus monodon. Lett Appl Microbiol 200:111-116

Marmur J (1961) A procedure for the isolation of deoxyribonucleic acid from microorganisms. J Mol Biol 3:208-218

Maximilien R, de Nys R, Holmstrom C, Gram L, Givskov M, Crass K, Kjelleberg S, Steinberg PD (1998) Chemical mediation of bacterial surface colonization by secondary metabolites from the red alga Delisea pulchra. Aquat Microb Ecol 15:233-246

McCaffrey EJ, Endean R (1985) Antimicrobial activity of tropical and subtropical sponges. Mar Biol 89:1-8

Mittleman MW (1996) Adhesion to biomaterials. In: Fletcher $M$ (ed) Bacterial adhesion: molecular and ecological diversity. John Wiley \& Sons, New York, p 1-24

Newbold RW, Jensen, PR, Fenical, W, Pawlik, JR (1999) Antimicrobial activity of Caribbean sponge extracts. Aquat Microb Ecol 19:279-284

Paul VJ (1992) Chemical defenses of benthic marine invertebrates. In: Paul VJ (ed) Ecological roles of marine natural products.Cornell University Press, Ithaca, NY, p 164-188

Pawlik JR (1992) Chemical ecology of the settlement of benthic marine invertebrates. Oceanogr Mar Biol Annu Rev 30:273-335

Pawlik JR (1993) Marine invertebrate chemical defenses. Chem Rev 93:1911-1922

Pawlik JR, Chanas B, Toonen RJ, Fenical W (1995) Defenses of Caribbean sponges against predatory reef fish. I. Chemical deterrency. Mar Ecol Prog Ser 127:183-194

Porter JW, Targett NM (1988) Allelochemical interactions between sponges and corals. Biol Bull (Woods Hole) 175: 230-239

Puyana M (2001) Chemical ecology of Caribbean sponges of the genus Aplysina. PhD dissertation, University of California, San Diego, CA

Reiswig HM (1973) Population dynamics of three Jamaican Demospongiae. Bull Mar Sci 23:191-226

Shea C, Lovelace LJ, Smith-Somerville HE (1995) Cobetia marina as a model organism for studies of bacterial colonization and biofilm formation. J Ind Microbiol 15(4): 290-296

Slattery M, McClintock JB, Heine JN (1995) Chemical defenses in Antarctic soft corals: evidence for antifouling compounds. J Exp Mar Biol Ecol 190:61-77

Sparks AK (1985) Synopsis of invertebrate pathology, exclusive of insects. Elsevier Science Publishers, New York

Steinberg PD (2001) Chemical mediation of surface colonization. In: McClintock JB, Baker BJ (eds) Marine chemical ecology. CRC Press, Boca Raton, FL, p 355-388

Steinberg PD, Schneider R, Kjelleberg S (1997) Chemical defenses of seaweeds against microbial colonization. Biodegradation 8:211-220

Stoecker D (1978) Resistance of a tunicate to fouling. Biol Bull (Woods Hole) 155:615-626

Thompson JE (1985) Exudation of biologically-active metabolites in the sponge Aplysina fistularis. I. Biological evidence. Mar Biol 88:23-26

Thompson JE, Barrow KD, Faulkner DJ (1983) Localization of two brominated metabolites, aerothionin and homoaerothionin in spherulous cells of the marine sponge, Aplysina fistularis (=Verongia thiona). Acta Zool Stockh 64:199-210 
Vacelet J, Donadey C (1977) Electron microscope study of the association between some sponges and bacteria. J Exp Mar Biol Ecol 30:301-314

Wahl M (1989) Marine epibiosis. I. Fouling and antifouling: some basic aspects. Mar Ecol Prog Ser 58:175-189

Wahl M, Banaigs B (1991) Marine epibiosis. III. Possible antifouling defense adaptations in Polysyncraton lacazei (Girad) (Didemnidae, Ascidiacea). J Exp Mar Biol Ecol 145:49-63

Editorial responsibility: James W. Ammerman, New Brunswick, New Jersey, USA
Wahl M, Jensen PR, Fenical W (1994) Chemical control of bacterial epibiosis on ascidians. Mar Ecol Prog Ser 110: 45-57

Willenz P, Hartman WD (1989) Micromorphology and ultrastructure of Caribbean sclerosponges. I. Ceratoporella nicholsoni and Stromatospongia norae (Ceratoporellidae, Porifera). Mar Biol 103:387-402

Zar JH (1999) Biostatistical analysis, 4th edn. Prentice Hall, Upper Saddle River, NJ

Submitted: October 29, 2004; Accepted: April 27, 2005

Proofs received from author(s): August 11, 2005 